\title{
Types of support expected by women treated due to gynaecological reasons during the peri-operative period
}

\section{Typy oczekiwanego wsparcia w okresie okołooperacyjnym u kobiet leczonych ginekologicznie}

\author{
Magdalena Lewicka ${ }^{1}$, Artur Wdowiak¹, Magdalena Sulima1, Barbara Stawarz², Szymon Bakalczuk², \\ Grzegorz Bakalczuk ${ }^{1}$
}

\author{
'Department of Obstetrics, Gynaecology and Obstetrical-Gynaecological Nursing Faculty of Nursing and Health Sciences, \\ Medical University, Lublin; \\ Head of Department: Prof. Henryk Wiktor, MD, PhD \\ 2Institute of Health Protection, Rev. Bronisław Markiewicz State Higher School of Technology and Economics, Jarosław; \\ Head of Institute: Irena Brukwicka, MD, PhD \\ ${ }^{3}$ Non-Public Health Care Unit 'Ovum Reproduction and Andrology', Lublin
}

Przegląd Menopauzalny 2013; 3: 216-222

\section{Summary}

Introduction: Women at the peri- and post-menopausal age who are qualified for surgical procedures for gynaecological reasons are exposed to specific emotional problems related with the necessity to perform the surgery. Therefore, they often expect various types of support. A characteristic feature of this support is an exchange of emotions, information, instruments for action and tangible property.

Aim of the study: The objective of the study was to perform an analysis of the type of support expected during the peri-operative period by women treated for gynaecological reasons.

Material and methods: The study covered 232 women at the pre- and peri-menopausal age who received surgical treatment for various gynaecological reasons. The study was carried out using an author-designed questionnaire form. The results of the study obtained were analysed statistically. The $p$ values $p<0.05$ were considered statistically significant.

Results: It was found out that respondents who had university education significantly more frequently $(p<0.05)$ expected information and instrumental support, compared to those with elementary/elementary vocational or secondary education level. In turn, patients who were married significantly more often expected emotional and information support, compared to those who were single. The respondents who had undergone a surgical procedure with considerable tissue injury significantly more frequently $(p<0.05)$ expected material support than women who had undergone surgery with moderate tissue injury.

Conclusions: The education level and marital status of patients determined the expectations of support during the peri-operative period, whereas patients' age and category of surgical procedure did not have any effect on the expectations of support during this time.

Key words: support, gynaecological surgery, peri-operative period.

\section{Streszczenie}

Wstęp: Kobiety w wieku około- i pomenopauzalnym, które kwalifikowane są do operacji z powodów ginekologicznych, narażone są na specyficzne problemy emocjonalne związane z koniecznością wykonania operacji, dlatego często oczekują różnego rodzaju wsparcia. Cechą charakterystyczną wsparcia jest wymiana emocji, informacji, instrumentów działania oraz dóbr materialnych.

Cel pracy: Celem pracy było dokonanie analizy rodzaju oczekiwanego wsparcia w okresie okołooperacyjnym $u$ kobiet leczonych z powodów ginekologicznych.

Materiał i metody: Badaniami objęto 232 kobiety w wieku przed- i okołomenopauzalnym, leczone operacyjnie z różnych powodów ginekologicznych. Badania przeprowadzono z zastosowaniem kwestionariusza ankiety 
własnego autorstwa. Uzyskane wyniki badań poddano analizie statystycznej. Przyjęto 5-procentowe ryzyko błędu wnioskowania, $p<0,05$ uznano za istotne statystycznie.

Wyniki: Stwierdzono, że badane z wykształceniem wyższym istotnie częściej $(p<0,05)$ oczekiwały wsparcia informacyjnego $\mathrm{i}$ instrumentalnego aniżeli pacjentki z wykształceniem podstawowym lub zawodowym oraz średnim. Z kolei badane zamężne istotnie częściej oczekiwały wsparcia emocjonalnego i informacyjnego aniżeli pacjentki samotne. Badane, u których wykonano operację ze znacznym urazem tkanek, istotnie częściej $(p<0,05)$ oczekiwały wsparcia rzeczowego aniżeli kobiety poddane operacji z miernym urazem tkanek.

Wnioski: Wykształcenie i stan cywilny pacjentek warunkowały oczekiwanie wsparcia w okresie okołooperacyjnym, natomiast wiek pacjentek i kategoria zabiegu operacyjnego nie warunkowały takiego oczekiwania.

Słowa kluczowe: wsparcie, operacje ginekologiczne, okres okołooperacyjny.

\section{Introduction}

While deciding about the scope of surgical treatment of a woman it is necessary to consider medical goals, evaluate the state of health, patient's expectations, and consent expressed by the woman to the type of surgery proposed [1-3]. According to Friebe [4], an acceptance and understanding by the woman of the surgical procedure proposed is of great importance in gynaecology. Patient's knowledge about the type of surgery, chances for its success and possible complications allow her to relatively precisely analyze the risk, which is usually related with injury, as well as the benefits of surgical treatment, and determines the emotional state of the patient.

The Expert Team of the Polish Gynaecological Association developed categorization of surgical procedures in gynaecology, taking into consideration the extent of tissue injuries. Four categories of surgical procedures in gynaecology were distinguished:

- category I - surgical procedures related with slight tissue injury;

- category II-surgical procedures related with moderate tissue injury;

- category III - surgical procedures associated with considerable tissue injury;

- category IV - surgical procedures related with extensive tissue injury [5].

Women at the peri- and post-menopausal age who are qualified for surgical procedures for gynaecological reasons, apart from the symptoms directly related with menopause, are exposed to specific emotional problems associated with the necessity to perform the surgery, and therefore, often expect various types of support.

Social support is a multi-dimensional concept, which may be variously defined. Sęk $[6,7]$ considers it as assistance available to an individual in difficult situations, possible to obtain due to interactions with others, which is a consequence of the affiliation of an individual to society. A characteristic feature of support is an exchange of emotions, information, instruments for action and material goods. Such an exchange may be one-sided or mutual, and its supporting-supported direction may be constant or alternating. It is important that this exchange accurately meets the demands of the person who is in a difficult situation $[8,9]$.

Irrespective of different opinions concerning the type of support, the following types are distinguished:

- Emotional support - consists in passing on supporting, reassuring emotions, which are the manifestation of concern and positive attitude towards the supported person in order to create the sense of affiliation, care and increase self-esteem. Due to the emotional support those who suffer may release themselves from own tensions and negative feelings, may express their anxiety, concerns, and sadness. Also, an adequate behaviour of the supporting person releases the sense of hopefulness.

- Informative support - consists in the exchange and provision of information and giving advice, which favour better understanding of the situation, own position in life and problems. Provision of feedback information concerning the effectiveness of undertaking by the supported person of various preventive measures, and sharing own experience with an individual experiencing similar problems also plays an important role. Informative support responds to the need for understanding the sense of critical events and their causes.

- Instrumental support - consists in passing on information pertaining to specific ways of conduct, and may take the form of the modelling of effective remedial behaviours.

- Tangible (material) support - consists in the provision of direct assistance, in the form of a loan, gift or service. Such a form of support may be, for example, acting on behalf of those in need: feeding, provision of shelter, residence, conveying financial support for living, provision with pharmaceuticals and medicinal products $[6-8,10]$.

The category of support may be considered and measured from structural or functional perspectives. Social structural support covers the category of the structure of interpersonal relationships. It enables an objective evaluation of mutual relationships between various types of social bonds. Social functional support makes it possible to evaluate whether these bonds fulfil their specified functions. Therefore, a division was made into perceived social support and received social support. 
Perceived support results from the knowledge and convictions of an individual concerning from whom and where he/she may obtain assistance in a difficult situation, whereas received support is objectively evaluated or subjectively reported by a recipient, as an actually received type and amount of support $[7,11]$. These two types of support exert an effect on the level of evaluation of stressful events, and may be associated with a lower intensity of negative emotions, or contribute to an increase in the sense of own resourcefulness, effectiveness, and independence. In the functional effect of support it is important to adjust received support to perceived support. According to Verheijden et al. [12], this type of support shows a strong correlation with health.

\section{Objective}

The objective of the study was to perform an analysis of the type of support expected during the peri-operative period among women treated for gynaecological reasons, according to socio-demographic variables and category of the surgical procedure.

\section{Material and methods}

The study covered 232 women at the pre- and perimenopausal age who received surgical treatment due to various gynaecological reasons at the Chairs II and III, Clinic of Gynaecology, Independent Public Clinical Hospital No. 4 in Lublin, and the Gynaecology and Obstetric Ward with Outpatient Department at the Cardinal Stefan Wyszyński Specialist Hospital in Lublin. Consent to the study was obtained from the Bioethical Commission at the Medical University in Lublin.

The study was conducted using a questionnaire form designed by the author for the needs of the presented investigations. The study was carried out in two stages: on the day preceding the surgery and on the third day after the surgical procedure. On these days, the respondents completed an identical questionnaire form. All the women in the study expressed their voluntary consent to complete the questionnaires, after being informed about the use of the results of the study only for scientific purposes and assurance of its anonymity.

Among patients who participated in the study there were 74 (31.90\%) patients aged 41-50, 80 women (34.48\%) aged over 50, and 78 (33.62\%) respondents aged up to 40. As many as 55 (23.7\%) patients had elementary or elementary vocational education, 115 (49.6\%) - secondary education, and 62 (26.7\%) - university education. Among the respondents, 157 (67.68\%) women were married, while 75 (32.32\%) patients were single.

The structure of the study group according to the type of surgical procedure was as follows: in the group of 167 (71.98\%) patients in the study, a surgical procedure with considerable tissue injury was performed, whereas in 65 (28.02\%) respondents the surgery was performed with moderate tissue injury. Among the surgical procedures with moderate tissue injury in 21 (32.31\%) patients surgical hysteroscopy was performed, in 13 (20.0\%) surgery due to vaginal prolapse, also in 13 (20.0\%) patients diagnostic laparoscopy was performed. In $10(15.38 \%)$ patients amputation of the cervix was performed, in 5 (7.69\%) the Burch colposuspension, while in 3 (4.62\%) - the Marshall-Marchetti-Krantz (MMK) colposuspension. In the group of patients who had undergone surgery with considerable tissue injury, simple abdominal hysterectomy was most frequently performed - 68 (40.72\%) patients, followed by surgical laparoscopy - 31 (18.55\%), myomectomy - 26 (15.57\%), and partial or complete surgical removal of the uterine body - in 20 (11.98\%) patients. Surgical treatment of endometriosis was performed in 9 (5.39\%) patients, 10 (5.99\%) respondents had undergone unilateral removal of the uterine appendages, while bilateral removal of the uterine appendages was performed in $3(1.80 \%)$ of the patients in the study.

The results of the studies obtained were analysed statistically using chi-square $\left(\mathrm{chi}^{2}\right)$ test for homogeneity by means of computer software STATISTICA 8.0 (StatSoft, Poland). The $p$ values $p<0.05$ were considered statistically significant.

\section{Results}

Table I presents the relationship between the type of support expected during the peri-operative period and patients' age.

The study showed that during the peri-operative period, patients aged 40 and under expected emotional, informative, instrumental and material support on a similar level as those aged 41-50, and also over 50. These differences were statistically insignificant $(p>0.05)$. The fact of performance of the procedure did not result in variation in the support expected by patients in the age groups compared. Also, during the post-operative period the respondents aged 40 and under expected emotional, informative, instrumental and material support on a level similar to those aged 41-50, and also over 50. These differences were statistically insignificant $(p>0.05)$.

Table II presents an analysis of the relationship between the type of perceived support during the perioperative period and the respondents' education level.

Based on the results of studies it was found that during the pre-operative period the patients with university education significantly more frequently expected informative support (69.35\%) and instrumental support (25.81\%), compared to those with secondary education (46.09\% and $11.30 \%$, respectively), and elementary or elementary vocational education level $(41.82 \%$ and $7.27 \%$, respectively). The statistical analysis performed 
Table I. Relationship between the type of expected support and the respondents' age during the peri-operative period

\begin{tabular}{|c|c|c|c|c|c|c|c|c|}
\hline \multirow{3}{*}{$\begin{array}{l}\text { Category } \\
\text { of surgical } \\
\text { procedure }\end{array}$} & \multicolumn{8}{|c|}{ Support expected before surgery* } \\
\hline & \multicolumn{2}{|c|}{ emotional } & \multicolumn{2}{|c|}{ informative } & \multicolumn{2}{|c|}{ instrumental } & \multicolumn{2}{|c|}{ material } \\
\hline & $n$ & $\%$ & $n$ & $\%$ & $n$ & $\%$ & $n$ & $\%$ \\
\hline up to 40 & 71 & 91.03 & 45 & 57.69 & 17 & 21.79 & 3 & 3.85 \\
\hline $41-50$ & 67 & 90.54 & 32 & 43.24 & 4 & 5.41 & 1 & 1.35 \\
\hline over 50 & 68 & 85.00 & 42 & 52.50 & 12 & 15.00 & 2 & 2.50 \\
\hline$\chi^{2}$ & \multicolumn{2}{|c|}{1.268} & \multicolumn{2}{|c|}{2.265} & \multicolumn{2}{|c|}{3.007} & \multicolumn{2}{|c|}{0.147} \\
\hline$p$ & \multicolumn{2}{|c|}{ NS } & \multicolumn{2}{|c|}{ NS } & \multicolumn{2}{|c|}{ NS } & \multicolumn{2}{|c|}{ NS } \\
\hline \multirow{3}{*}{$\begin{array}{l}\text { Category } \\
\text { of surgical } \\
\text { procedure }\end{array}$} & \multicolumn{8}{|c|}{ Support expected after surgery* } \\
\hline & \multicolumn{2}{|c|}{ emotional } & \multicolumn{2}{|c|}{ informative } & \multicolumn{2}{|c|}{ instrumental } & \multicolumn{2}{|c|}{ material } \\
\hline & $n$ & $\%$ & $n$ & $\%$ & $n$ & $\%$ & $n$ & $\%$ \\
\hline up to 40 & 68 & 87.18 & 44 & 56.41 & 19 & 24.36 & 2 & 2.56 \\
\hline $41-50$ & 64 & 86.49 & 44 & 59.46 & 10 & 13.51 & 3 & 4.05 \\
\hline over 50 & 68 & 85.00 & 35 & 43.75 & 13 & 16.25 & 3 & 3.75 \\
\hline$\chi^{2}$ & \multicolumn{2}{|c|}{0.589} & \multicolumn{2}{|c|}{1.898} & \multicolumn{2}{|c|}{1.740} & \multicolumn{2}{|c|}{0.159} \\
\hline$p$ & \multicolumn{2}{|c|}{ NS } & \multicolumn{2}{|c|}{ NS } & \multicolumn{2}{|c|}{ NS } & \multicolumn{2}{|c|}{ NS } \\
\hline
\end{tabular}

*the respondents provided more than one reply

Table II. Relationship between the type of support expected during the peri-operative period and the respondents' education level

\begin{tabular}{|c|c|c|c|c|c|c|c|c|}
\hline \multirow[t]{3}{*}{ Category of surgical procedure } & \multicolumn{8}{|c|}{ Support expected before surgery* } \\
\hline & \multicolumn{2}{|c|}{ emotional } & \multicolumn{2}{|c|}{ informative } & \multicolumn{2}{|c|}{ instrumental } & \multicolumn{2}{|c|}{ material } \\
\hline & $n$ & $\%$ & $n$ & $\%$ & $n$ & $\%$ & $n$ & $\%$ \\
\hline elementary or elementary vocational & 47 & 85.45 & 23 & 41.82 & 4 & 7.27 & 0 & 0.00 \\
\hline secondary & 101 & 87.83 & 53 & 46.09 & 13 & 11.30 & 6 & 5.22 \\
\hline university & 58 & 93.55 & 43 & 69.35 & 16 & 25.81 & 0 & 0.00 \\
\hline$\chi^{2}$ & \multicolumn{2}{|c|}{3.598} & \multicolumn{2}{|c|}{7.899} & \multicolumn{2}{|c|}{6.448} & \multicolumn{2}{|c|}{1.287} \\
\hline$p$ & \multicolumn{2}{|c|}{ NS } & \multicolumn{2}{|c|}{$<0.02$} & \multicolumn{2}{|c|}{$<0.05$} & \multicolumn{2}{|c|}{ NS } \\
\hline \multirow[t]{3}{*}{ Category of surgical procedure } & \multicolumn{8}{|c|}{ Support expected after surgery* } \\
\hline & \multicolumn{2}{|c|}{ emotional } & \multicolumn{2}{|c|}{ informative } & \multicolumn{2}{|c|}{ instrumental } & \multicolumn{2}{|c|}{ material } \\
\hline & $n$ & $\%$ & $n$ & $\%$ & $n$ & $\%$ & $n$ & $\%$ \\
\hline elementary or elementary vocational & 42 & 76.36 & 23 & 41.82 & 7 & 12.73 & 2 & 3.64 \\
\hline secondary & 102 & 88.70 & 61 & 53.04 & 19 & 16.52 & 4 & 3.48 \\
\hline university & 56 & 90.32 & 39 & 62.90 & 16 & 25.81 & 2 & 3.23 \\
\hline$\chi^{2}$ & \multicolumn{2}{|c|}{4.228} & \multicolumn{2}{|c|}{6.517} & \multicolumn{2}{|c|}{6.210} & \multicolumn{2}{|c|}{1.278} \\
\hline$p$ & \multicolumn{2}{|c|}{ NS } & \multicolumn{2}{|c|}{$<0.05$} & \multicolumn{2}{|c|}{$<0.05$} & \multicolumn{2}{|c|}{ NS } \\
\hline
\end{tabular}

*the respondents provided more than one reply

showed a statistically significant relationship between the expectations of informative support $(p<0.02)$ and instrumental support $(p<0.05)$ during the pre-operative period, and the respondents' education level. However, no statistically significant difference was observed $(p>0.05)$ between the expectations of emotional and material support during the pre-operative period, according to the respondents' education level. The percentage distributions determining the expectations of support during the post-operative period did not considerably change according to the respondents' education level. Also, during the post-operative period, women who had university education more frequently expected informative support (62.90\%) and instrumental support (25.81\%) than the respondents who had secondary education (53.04\% and $16.52 \%$, respectively), and elementary or elementary vocational education $(41.82 \%$ and $12.73 \%$, respectively). A statistically significant relationship was confirmed between the expectations of informative support $(p<0.05)$ and instrumental support $(p<0.05)$ during the post-operative period, and the education level of the patients examined. However, no statistically significant difference was found $(p>0.05)$ between expectations of social and material support 
Table III. Relationship between the type of expected support and respondents' marital status during the peri-operative period

\begin{tabular}{|c|c|c|c|c|c|c|c|c|}
\hline \multirow{3}{*}{$\begin{array}{l}\text { Category } \\
\text { of surgical } \\
\text { procedure }\end{array}$} & \multicolumn{8}{|c|}{ Support expected before surgery* } \\
\hline & \multicolumn{2}{|c|}{ emotional } & \multicolumn{2}{|c|}{ informative } & \multicolumn{2}{|c|}{ instrumental } & \multicolumn{2}{|c|}{ material } \\
\hline & $n$ & $\%$ & $n$ & $\%$ & $n$ & $\%$ & $n$ & $\%$ \\
\hline single & 58 & 77.33 & 29 & 38.67 & 11 & 14.67 & 2 & 2.67 \\
\hline married & 148 & 94.27 & 90 & 57.32 & 22 & 14.01 & 4 & 2.55 \\
\hline$\chi^{2}$ & \multicolumn{2}{|c|}{8.457} & \multicolumn{2}{|c|}{10.569} & \multicolumn{2}{|c|}{0.259} & \multicolumn{2}{|c|}{0.477} \\
\hline$p$ & \multicolumn{2}{|c|}{$<0.02$} & \multicolumn{2}{|c|}{$<0.01$} & \multicolumn{2}{|c|}{ NS } & \multicolumn{2}{|c|}{ NS } \\
\hline \multirow{3}{*}{$\begin{array}{l}\text { Category } \\
\text { of surgical } \\
\text { procedure }\end{array}$} & \multicolumn{8}{|c|}{ Support expected after surgery* } \\
\hline & \multicolumn{2}{|c|}{ emotional } & \multicolumn{2}{|c|}{ informative } & \multicolumn{2}{|c|}{ instrumental } & \multicolumn{2}{|c|}{ material } \\
\hline & $n$ & $\%$ & $n$ & $\%$ & $n$ & $\%$ & $n$ & $\%$ \\
\hline single & 56 & 74.67 & 33 & 44.00 & 12 & 16,00 & 4 & 5,33 \\
\hline married & 144 & 91.72 & 90 & 57.32 & 30 & 19,11 & 4 & 2,55 \\
\hline$\chi^{2}$ & \multicolumn{2}{|c|}{8,598} & \multicolumn{2}{|c|}{7.458} & \multicolumn{2}{|c|}{3.569} & \multicolumn{2}{|c|}{2.659} \\
\hline$p$ & \multicolumn{2}{|c|}{$<0.02$} & \multicolumn{2}{|c|}{$<0.02$} & \multicolumn{2}{|c|}{ NS } & \multicolumn{2}{|c|}{ NS } \\
\hline
\end{tabular}

Table IV. Relationship between the type of support expected and category of surgical procedure during the peri-operative period

\begin{tabular}{|c|c|c|c|c|c|c|c|c|}
\hline \multirow[t]{3}{*}{ Category of surgical procedure } & \multicolumn{8}{|c|}{ Support expected before surgery* } \\
\hline & \multicolumn{2}{|c|}{ emotional } & \multicolumn{2}{|c|}{ informative } & \multicolumn{2}{|c|}{ instrumental } & \multicolumn{2}{|c|}{ material } \\
\hline & $n$ & $\%$ & $n$ & $\%$ & $n$ & $\%$ & $n$ & $\%$ \\
\hline moderate tissue injury & 55 & 84.62 & 31 & 47.69 & 9 & 13.85 & 2 & 3.08 \\
\hline considerable tissue injury & 151 & 90.42 & 88 & 52.69 & 24 & 14.37 & 4 & 2.40 \\
\hline$\chi^{2}$ & & & & & & & & \\
\hline$p$ & & & & & & & & \\
\hline \multirow[t]{3}{*}{ Category of surgical procedure } & \multicolumn{8}{|c|}{ Support expected after surgery* } \\
\hline & \multicolumn{2}{|c|}{ emotional } & \multicolumn{2}{|c|}{ informative } & \multicolumn{2}{|c|}{ instrumental } & \multicolumn{2}{|c|}{ material } \\
\hline & $n$ & $\%$ & $n$ & $\%$ & $n$ & $\%$ & $n$ & $\%$ \\
\hline moderate tissue injury & 53 & 81.54 & 30 & 46.15 & 24 & 36.92 & 8 & 12.31 \\
\hline considerable tissue injury & 143 & 85.63 & 79 & 47.31 & 57 & 34.13 & 37 & 22.16 \\
\hline$\chi^{2}$ & \multicolumn{2}{|c|}{2.268} & \multicolumn{2}{|c|}{0.144} & \multicolumn{2}{|c|}{1028} & \multicolumn{2}{|c|}{6.598} \\
\hline$p$ & \multicolumn{2}{|c|}{ NS } & \multicolumn{2}{|c|}{ NS } & \multicolumn{2}{|c|}{ NS } & \multicolumn{2}{|c|}{$<0.05$} \\
\hline
\end{tabular}

during the post-operative period, and the respondents' education level.

Table III shows the relationship between the type of support expected during the peri-operative period and the respondents' marital status.

Marital status considerably determined the respondents' expectations of emotional and informative support during the pre-operative period. Single women (unmarried, widowed, divorced) considerably less frequently expected emotional support (77.33\%) and informative support (38.67\%), compared to the married women ( $94.77 \%$ and $57.32 \%$, respectively). In both cases, a statistically significant relationship was observed at a level of $p<0.02$ and $p<0.01$, respectively. During the post-operative period, married women also considerably more often expected emotional support (91.72\%) and informative support (57.32\%), compared to those who were single $(74.67 \%$ and $44.00 \%$, respectively). During the post-operative period a statistically significant relationship was noted between the expectation of emotional support $(p<0.02)$ and informative support ( $p<0.02$ ), and the marital status of the women in the study. Nevertheless, no statistically significant relationship was observed $(p>0.05)$ between expectations of instrumental and material support, and the respondents' marital status, both during the preoperative and post-operative periods.

Table IV presents relationship between the type of support expected during the pre- and post-operative periods, and the category of the surgical procedure.

The study showed that patients in whom surgery was planned with moderate tissue injury slightly more rarely expected emotional support (84.62\%) and informative support $(47.69 \%)$ during the pre- 
operative period, compared to those in whom surgery was planned with considerable tissue injury $(90.42 \%$ and $52.69 \%$, respectively). However, this difference was statistically insignificant $(p>0.05)$, similar to the expected instrumental and material support $(p>0.05)$. Also, during the post-operative period, the women who had undergone surgery with a moderate tissue injury slightly more rarely expected emotional support (81.54\%) and informative support (46.15\%), compared to the women who had undergone surgery with considerable tissue injury (emotional support - 85.63\%, informative support - 47.31\%). This difference was not statistically significant $(p>0.05)$. Nevertheless, during the postoperative period, a statistically significant relationship was found $(p<0.05)$ between the category of surgical procedure and expectation of material support in the group of patients. The respondents who had undergone surgery with a considerable tissue injury significantly more frequently expected material support (22.16\%) than those who had undergone surgical treatment with moderate tissue injury (12.31\%). However, among the patients in the study, no statistically significant differences were observed $(p>0.05)$ between the category of surgical procedure and expectations of emotional, informative and instrumental support during the post-operative period.

\section{Discussion}

Women, irrespective of age, perceive gynaecological surgical procedures as a form of mutilation, which is associated with the violation of physical integrity, disturbed body image, and decreased self-esteem. Therefore, during the peri-operative period, it is important to identify patients with a low level of personal and social resources, in order to provide them with an adequate type of support [13-15].

Salmon [16] emphasizes that social support is especially important for hospitalized patients, because it serves as their protection against physiological and emotional stress responses. According to this researcher, the obtaining of support from the medical staff and others is related with a lower level of anxiety and depression, and better adaptation after the surgery. Social support is an important factor which results in the restoration and increase in the sense of coherence, and when provided by a family or other social network, may help the patient to perceive her own situation as understandable, steerable and meaningful [17]. The studies by Łepecka-Klusek et al. [18] show that older women (aged > 49 years) significantly more often than those younger (aged $\leq 49$ years) expect support mainly from the medical staff, because in their opinion, they may less often count on support from their family than the younger patients.

Lindberg and Nolan [19] consider that it is important to provide women with adequate informative and emo- tional support during the period of decision making concerning surgical treatment. The patients' need for emotional support, to a great extent, is due to their being insufficiently informed about the goal of surgical treatment and the surgical method [20]. The presented study shows that during the pre-operative period the patients expected emotional, informative, instrumental and material support on a similar level, irrespective of their age. In turn, considering the respondents' education level, in own studies it was observed that during the pre-operative period patients with university education considerably more often expected informative and instrumental support, compared to those with elementary/elementary vocation or secondary education. Also, married women significantly more frequently expected emotional and informative support than those who were single.

The effect of social support on the self-reported and objective indicators of stress during the perioperative period was investigated by Krohne and Slangen [21]. The results of the studies obtained showed that patients who received high social support were characterized by a lower level of anxiety, were administered lower doses of anaesthetics, and the duration of their hospitalization was considerably shorter, compared to patients who received poor support during the peri-operative period. According to Chan et al. [22], during the post-operative period, the obtaining of material and informative support is more important for patients than emotional support. Studies conducted by Bunde et al. [23] showed that patients who had undergone hysterectomy received high emotional and material support from their closest surroundings. However, despite this, the abovementioned patients considerably more frequently sought for information and advice from other women who had undergone a similar surgical procedure, than sought emotional support. The presented study shows that age did not determine the type of expected support during the post-operative period. Nevertheless, the type of expected support depended on the education level and marital status of the women examined. In own studies, it was observed that during the postoperative period the patients with university education considerably more often expected informative and instrumental support, compared to respondents with an elementary/elementary vocational or secondary education level. In turn, married women significantly more frequently expected emotional and informative support than women who were single. No significant differences were found between the category of the surgical procedure and expectations of emotional, informative, instrumental or material support in the group of patients examined, during the pre-operative and post-operative periods. 


\section{Conclusions}

1. Patients' age did not determine the expectation of support during the peri-operative period.

2. The education level and marital status of patients determined expectation of support during the perioperative period. The respondents with university education significantly more frequently expected informative and instrumental support, compared to patients with elementary/elementary vocational or secondary education level. In turn, married women significantly more often expected emotional and informative support than patients who were single.

3. The category of the surgical procedure did not determine the expected emotional, informative, instrumental and material support during the preoperative period. However, during the post-operative period, only material support was determined by the category of the surgical procedure. The respondents who had undergone surgery with a considerable tissue injury significantly more frequently expected material support, compared to those who had undergone surgery with moderate tissue injury.

\section{References}

1. Bidzan $M$. Ja realne i ja idealne $u$ kobiet operowanych radykalnie i zachowawczo z powodu guzów łagodnych i nienowotworowych narządów rodnych. Psychoonkologia 2003; 7: 101-7.

2. Kotarski J. Leczenie mięśniaków macicy metodą embolizacji tętnic macicznych. W: Spaczyński M (red.). Postępy w ginekologii i położnictwie. Polskie Towarzystwo Ginekologiczne, Poznań 2006.

3. Skręt A. Współczesne operacje ginekologiczne. W: Postępy w ginekologii i położnictwie. Spaczyński M (red.). Polskie Towarzystwo Ginekologiczne, Poznań 2006

4. Friebe Z. Operacyjne leczenie w ginekologii. W: Położnictwo i ginekologia. Bręborowicz G (red.). Wydawnictwo Lekarskie PZWL, Warszawa 2007.

5. Rekomendacje dotyczące postępowania przeciwbólowego w ginekologii i położnictwie część pierwsza: leczenie bólu po zabiegach ginekologicznych. Lubelski Biuletyn Ginekologiczno-Położniczy 2007; 2: 35-43.

6. Sęk H. O wieloznacznych funkcjach wsparcia społecznego. W: Psychologia kliniczna i psychologia zdrowia. Cierpiałkowska L, Sęk H (red.). Wydawnictwo Humaniora, Poznań 2001; 13-33.
7. Sęk H, Cieślak R. Wsparcie społeczne - sposoby definiowania, rodzaje i źródła wsparcia, wybrane koncepcje teoretyczne. W: Wsparcie społeczne, stres i zdrowie. Sęk H, Cieślak R (red.). Wydawnictwo Naukowe PWN, Warszawa 2006; 11-29.

8. Skwara A, Kolarzyk E. Rola i znaczenie wsparcia społecznego w radzeniu sobie ze stresem. Medycyna Środowiskowa 2002; 5: 15-8.

9. Dyga-Konarska M. Informacyjne i emocjonalne wsparcie pacjenta przez personel medyczny. Standardy Medyczne 2004; 5: 599-604.

10. Piotrkowska R, Książek J, Kolka A. Wsparcie w procesie pielęgnowania osób niepełnosprawnych. Pielęgniarka i Położna 2005; 7-8: 4-5.

11. Skrzypek M, Widomska-Czekajska T. Znaczenie wsparcia społecznego dla stanu zdrowia pacjentów z chorobą wieńcową kwalifikowanych do koronarografii. Zdr Publ 2004; 114: 46-51.

12. Verheijden MW, Bakx JC, van Weel C, et al. Role of social support in lifestyle-focoused weight management interventions. Eur J Clin Nutr 2005; supp. 1: 179-86.

13. Wilczak M, Mojs E, Samulak D, et al. Wpływ operacji ginekologicznych na stopień zaburzeń snu oraz emocji u kobiet w wieku około- i pomenopauzalnym. Prz Menopauz 2011; 5: 393-9.

14. Malicka I, Szczepańska J, Anioł K, et al. Zaburzenia nastroju i strategie przystosowania do choroby u kobiet leczonych operacyjnie z powodu nowotworu piersi i narządów rodnych. Współczesna Onkol 2009; 13: 41-6.

15. Rannestad T. Hysterectomy: effects on quality of life and psychological aspects. Best Pract Res Clin Obstet Gynaecol 2005; 19: 419-30.

16. Salmon P. Psychologia w medycynie. Gdańskie Wydawnictwo Psychologiczne, Gdańsk 2002.

17. Skarsater I, Langius A, Agren $\mathrm{H}$, et al. Sense of coherence and social support in relation to recovery in first-episode patients with major depression: a one-year prospective study. Int J Ment Health Nurs 2005; 14 : 258-64.

18. Łepecka-Klusek C, Pilewska-Kozak AB, Syty K, Jakiel G. Potrzeba wsparcia psychicznego kobiet w okresie oczekiwania na operację ginekologiczną. Prz Menopauz 2010; 5: 309-14.

19. Lindberg CE, Nolan LB. Women's decision making regarding hysterectomy. J Obstet Gynecol Neonatal Nurs 2001; 30: 607-16.

20. Łuczyńska V, Grochans E, Ćwiek D. Wsparcie emocjonalne jako element pracy pielęgniarki-położnej $\mathrm{w}$ oddziale ginekologii operacyjnej. Pielęgniarstwo XXI wieku 2003; 3: 13-8.

21. Krohne HW, Slangen KE. Influence of social support on adaptation to surgery. Health Psychol 2005; 24: 101-5.

22. Chan CW, Hon HC, Chien WT, Lopez V. Social support and coping in Chinese patients undergoing cancer surgery. Cancer Nurs 2004; 27: 230-6.

23. Bunde M, Suls J, Martin R, Barnett K. Hystersisters online: social support and social comparison among hysterectomy patients on the internet. Ann Behav Med 2006; 31: 271-8. 